\title{
Pichia myanmarensis sp. nov., a novel cation-tolerant yeast isolated from palm sugar in Myanmar
}

\author{
Yuka Nagatsuka, Hiroko Kawasaki and Tatsuji Seki \\ The International Center for Biotechnology, Osaka University, 2-1 Yamada-oka, Suita-city, \\ Osaka 565-0871, Japan
}

Correspondence

Hiroko Kawasaki

ICBKawasakiNakagawa@

icb.osaka-u.ac.jp

\begin{abstract}
Four halotolerant yeast strains, $\mathrm{M} 21^{\top}, \mathrm{M} 34-1, \mathrm{HS} 054$ and $\mathrm{D} 41$, were isolated from various foods in South-East Asia. These isolates were most closely related to Pichia anomala, with which each strain had from zero to two differences in the 26S rDNA D1/D2 domain nucleotide sequence; for this reason, they were thought to be the same as, or sister species of, $P$. anomala. Of the four yeast isolates, only one strain, $\mathrm{M} 21^{\top}$, had an $18 \mathrm{~S}$ rDNA sequence that differed from those of $P$. anomala IFO $10213^{\top}$ and the other three isolates, having 20 substitutions and two gaps. Strain $\mathrm{M} 21^{\top}$ showed lower cation $\left(\mathrm{Li}^{+}\right)$tolerance $(\leqslant 0.3 \mathrm{M} \mathrm{LiCl})$ than $P$. anomala IFO $10213^{\top}$ or the other three strains $(\leqslant 0.5 \mathrm{M} \mathrm{LiCl})$. Furthermore, the DNA-DNA hybridization data indicated that $\mathrm{M} 21^{\top}$ was clearly distinct from $P$. anomala IFO $10213^{\top}$ and the other three isolates. The ability of strain $\mathrm{M} 21^{\top}$ to assimilate $\mathrm{D}$-arabinose distinguished it from $P$. anomala IFO $10213^{\top}$ and the other three isolates; it also differed in that it was able to grow at 37 and $40{ }^{\circ} \mathrm{C}$. Strain $\mathrm{M} 21^{\top}$ grew by multilateral budding, produced persistent asci, in which between one and four hat-shaped ascospores were formed, and contained ubiquinone Q-7. On the basis of this polyphasic characterization, strain $\mathrm{M} 21^{\top}$ represents a novel species within the Q-7-containing group of the genus Pichia, for which the name Pichia myanmarensis is proposed. The type strain is $M 21^{\top}\left(=\operatorname{NBRC} 11090^{\top}=\mathrm{JCM} 12922^{\top}=\mathrm{CBS} 9786^{\top}\right)$.
\end{abstract}

We have studied the taxonomic diversity of yeasts isolated from general and traditional fermented foods in SouthEast Asia. All of the yeast isolates were identified, on a preliminary basis, from analyses of the $26 \mathrm{~S}$ rDNA D1/D2 domain sequences. The cation $\left(\mathrm{Li}^{+}\right)$tolerance of each isolate was tested using its ability to grow in YM broth supplemented with $\mathrm{LiCl}$. As a result of these surveys, four isolates were discovered whose 26S rDNA D1/D2 domain sequences were similar to that of Pichia anomala NRRL Y-366 (GenBank accession no. U74592). Of these, one isolate, $\mathrm{M} 21^{\mathrm{T}}$, whose $26 \mathrm{~S}$ rDNA D1/D2 sequence differed at two positions from that of $P$. anomala NRRL Y-366, showed cation $\left(\mathrm{Li}^{+}\right)$tolerance $(\leqslant 0 \cdot 3 \mathrm{M} \mathrm{LiCl})$ that was lower than those of $P$. anomala IFO $10213^{\mathrm{T}}$ and the other three isolates $(\leqslant 0 \cdot 5 \mathrm{M} \mathrm{LiCl})$. Accordingly, other taxonomic characteristics of $\mathrm{M} 21^{\mathrm{T}}$ were determined and the strain was shown

The GenBank/EMBL/DDBJ accession numbers for the 26S rDNA D1/D2 domain sequences of $P$. anomala strains D41, HS054 and M34-1 and $P$. myanmarensis $M 21^{\top}$ are AB126675-AB126678. The accession numbers for the $18 \mathrm{~S}$ rDNA sequences of $P$. anomala strains IFO $10213^{\top}, \mathrm{D} 41, \mathrm{HSO} 54$ and M34-1 and $P$. myanmarensis $\mathrm{M} 21^{\top}$ are AB126679-AB126683.

Differential characteristics for strains of $P$. myanmarensis and $P$. anomala are available in a supplementary table in IJSEM Online. to represent a novel species within the Q-7-containing group of the genus Pichia.

In Mandalay (Myanmar) in 2000, yeast strains $\mathrm{M}_{2} 1^{\mathrm{T}}$ and M34-1 were isolated from palm sugar collected from the floor of a storage room in a rum distillery and also from sap that had oozed out onto the skins of bananas being sold at a market. The strains were isolated by enrichment culture using $20 \%(\mathrm{w} / \mathrm{v})$ YM medium at $28^{\circ} \mathrm{C}$. Strains HS054 and D41 had been collected previously in a project supported by the Special Coordination Funds of the Japan Science and Technology Agency, between 1995 and 1999. Strain HS054 came from saccharified red rice (kao mark) in Surat Thani, Thailand, and had been kept in a laboratory in Thailand. The method used for isolating strain HS054 is unknown. Strain D41 was isolated from fermented glutinous rice (tape ketan) in Indonesia. The isolation was carried out as follows. Ringer's solution, in which the isolation source had been placed and incubated for 1 day, was streaked onto a medium containing $6 \mathrm{~g}$ malt extract, $1.5 \mathrm{~g}$ yeast extract, $350 \mathrm{~g}$ glucose, $350 \mathrm{~g}$ fructose and $6 \mathrm{~g}$ agar in $300 \mathrm{~g}$ water $\left(a_{\mathrm{W}}=0 \cdot 76\right)$. All isolates and $P$. anomala IFO $10213^{\mathrm{T}}$ were cultivated in YM medium at $24^{\circ} \mathrm{C}$ and stored in $15 \%$ glycerol at $-80{ }^{\circ} \mathrm{C}$. The rRNA gene sequences were analysed as described previously (Nagatsuka et al., 
2002; Yamada et al., 1999). Primers NL-1 and NL-4 (O'Donnell, 1993) were used to synthesize and sequence the D1/D2 domain fragments of the 26S rDNA. Primers P1 and P2 were used to synthesize the 18S rDNA fragments, while primers P1-P8 (Yamada et al., 1999) were used to sequence the $18 \mathrm{~S}$ rDNA. Phylogenetic trees were constructed on the basis of an alignment of $1642 \mathrm{nt} 18 \mathrm{~S}$ rDNA (1692 nt determined), excluding gaps, uncertain positions within the sequence retrieved from the database (designated $\mathrm{n})$ and ambiguously aligned regions in considering the secondary structure of 18S rRNA (Gutell, 1993); nucleotide positions 131-135, 191-194, 231-234, 276-280, 491-496, 662-666, 678-682, 709-719, 1055-1064, 1354-1372 and 1490-1491, according to the Saccharomyces cerevisiae numbering system (James et al., 1997) (Fig. 1), were excluded from the analysis. Ascospores were prepared for scanning electron microscopy (model JSM-5400; JEOL) using the method employed by Mikata \& Nakase (1997). Physiological tests were performed using the standard protocols described by Yarrow (1998). The effect of osmotic pressure on growth was determined by a strain's ability to grow at high sugar concentrations (50 or $60 \%$, w/w, glucose; Yarrow, 1998). Cation tolerance was determined by a strain's ability to grow in YM broth ( $\mathrm{pH}$ 6.2) supplemented with $\mathrm{NaCl}$ or $\mathrm{LiCl}$ at various concentrations, as previously described (Nagatsuka et al., 2002). The quinone systems were determined by using HPLC (Yamada et al., 1973; Kuraishi et al., 1985). Nuclear DNA for determination of the DNA G $+\mathrm{C}$ content and for DNA-DNA hybridization was extracted and purified, using a modified version of the method of Marmur (1961), from cells treated with Zymolyase 20T (Seikagaku). Nuclear DNA was purified by equilibrium ultracentrifugation in $\mathrm{CsCl} /$ ethidium-bromide gradients according to the method of Hamamoto \& Nakase (1995), using an ultracentrifuge (Hitachi CS-210) at $400000 \mathrm{~g}$ for $5 \mathrm{~h}$. The DNA G+C content was determined according to the HPLC method of Tamaoka \& Komagata (1984). DNA-DNA hybridization and detection of biotinylated DNA were carried out as described previously (Nagatsuka et al., 2002). Hybridization for isolate
$\mathrm{M} 21^{\mathrm{T}}$ was performed at $44^{\circ} \mathrm{C}$ in a $2 \times$ SSC buffer containing $50 \%(\mathrm{v} / \mathrm{v})$ formamide on an immunoplate (Nunc).

We determined $573 \mathrm{nt}$ of the 26S rDNA D1/D2 domain sequence of each of the four isolates (M21 ${ }^{\mathrm{T}}, \mathrm{M} 34-1, \mathrm{HS} 054$ and D41). The sequence of strain D41 was identical to that of P. anomala NRRL Y-366, whereas isolates M21 ${ }^{\mathrm{T}}, \mathrm{M} 34-1$ and HS054 differed from P. anomala NRRL Y-366 at two, one and one position(s) of the $573 \mathrm{nt}$, respectively. Analysis of the 26S rDNA D1/D2 sequence therefore suggested that these four isolates belong to $P$. anomala or a closely related species, on the basis of the generalizations of Kurtzman \& Robnett (1998). The 18S rDNA sequences of three of the isolates, M34-1, HS054 and D41, were identical to that of P. anomala IFO $10213^{\mathrm{T}}$, but the sequence of $\mathrm{M} 21^{\mathrm{T}}$ differed from the others by 20 substitutions and two gaps. The positions of the 20 substitutions were clustered and not scattered. Specifically, 10 of the substitutions were located in the V9 variable region (De Rijk et al., 1992), while four others were located in the loop connecting the E21-2 and $\mathrm{E} 21-5$ helices in the V4 region. Isolate $\mathrm{M} 21^{\mathrm{T}}$ formed a wellsupported (99\%) cluster with $P$. anomala, Candida silvicultrix and Pichia sydowiorum within a clade containing Q-7-containing species of Pichia and Williopsis (Fig. 1). These levels of sequence similarity show that isolate $\mathrm{M} 21^{\mathrm{T}}$ is clearly divergent from C. silvicultrix and P. sydowiorum.

We compared the cation tolerance and osmotolerance of the four isolates and P. anomala IFO $10213^{\mathrm{T}}$. All strains grew in $10 \% \mathrm{NaCl}$ plus $5 \%$ glucose and 0,1 and $2 \mathrm{M} \mathrm{NaCl}$ broth but not in $3 \mathrm{M} \mathrm{NaCl}$. P. anomala IFO $10213^{\mathrm{T}}$ and three of the isolates, M34-1, HS054 and D41, grew in broth containing $0.5 \mathrm{M} \mathrm{LiCl}$ and $50 \%$ glucose agar, but isolate $\mathrm{M} 21^{\mathrm{T}}$ did not. $\mathrm{M} 21^{\mathrm{T}}$ clearly differed from $P$. anomala and the other three isolates in terms of its tolerance of cation $\left(\mathrm{Li}^{+}\right)$ toxicity or osmotic pressure. The DNA relatedness values for the five strains (Table 1) demonstrated that $\mathrm{M} 21^{\mathrm{T}}$ is distinct from $P$. anomala IFO $10213^{\mathrm{T}}$, and that the other three isolates, M34-1, HS054 and D41, are members of $P$. anomala. The DNA G $+\mathrm{C}$ contents of $\mathrm{M} 21^{\mathrm{T}}$ and of $P$. anomala, including strains M34-1, HS054 and D41, were

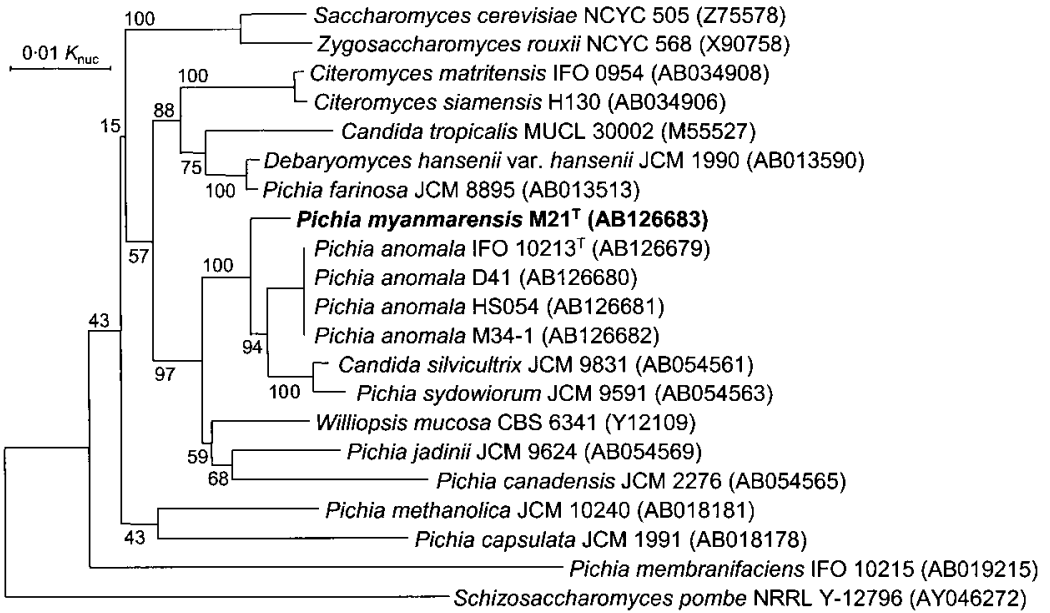

Fig. 1. Phylogenetic positions of Pichia myanmarensis sp. nov., based on the $18 \mathrm{~S}$ rDNA sequence. The phylogenetic tree was constructed by the neighbour-joining method, based on $1642 \mathrm{nt}$, using Kimura's two-parameter distance correction. Numerals indicate bootstrap values, expressed as percentages of 1000 samples. Bar, distance corresponding to $1 \mathrm{nt}$ change per $100 \mathrm{nt}$ positions. 
Table 1. Levels of DNA relatedness for $P$. anomala and $P$. myanmarensis

\begin{tabular}{|c|c|c|c|c|c|}
\hline \multirow[t]{2}{*}{ Strain } & \multicolumn{5}{|c|}{ Relative binding (\%) with labelled DNA from: } \\
\hline & IFO $10213^{T}$ & D41 & HS054 & M34-1 & $\mathrm{M} 21^{\mathrm{T}}$ \\
\hline P. anomala IFO $10213^{\mathrm{T}}$ & 100 & $93 \cdot 6$ & $113 \cdot 1$ & 100 & $38 \cdot 9$ \\
\hline P. anomala D41 & $74 \cdot 5$ & 100 & $94 \cdot 8$ & $97 \cdot 0$ & $33 \cdot 7$ \\
\hline P. anomala HS054 & $78 \cdot 2$ & $92 \cdot 3$ & 100 & $100 \cdot 5$ & $30 \cdot 6$ \\
\hline P. anomala M34-1 & $72 \cdot 3$ & $93 \cdot 2$ & $90 \cdot 1$ & 100 & $29 \cdot 5$ \\
\hline P. myanmarensis $\mathrm{M} 21^{\mathrm{T}}$ & $25 \cdot 9$ & $27 \cdot 2$ & $24 \cdot 6$ & $30 \cdot 5$ & 100 \\
\hline
\end{tabular}

$32 \cdot 2-33 \cdot 2$ and $33 \cdot 6-34 \cdot 8 \mathrm{~mol} \%$, respectively. In the other physiological and biochemical tests, isolate $\mathrm{M} 21^{\mathrm{T}}$ showed features similar to those of $P$. anomala IFO $10213^{\mathrm{T}}$, including the other three isolates, but differed in terms of $\mathrm{D}$ arabinose assimilation and growth at 37 and $40^{\circ} \mathrm{C}$. In all isolates, the major ubiquinone was Q-7, as in P. anomala. In $\mathrm{M} 21^{\mathrm{T}}$, persistent asci arose from diploid cells, with each ascus forming between one and four hat-shaped ascospores on ME agar (Fig. 2), cornmeal, acetate and YM agar after incubation at $24{ }^{\circ} \mathrm{C}$ for 3 days. Thus, on the basis of the phenotypic, phylogenetic and genomic distinctiveness of strain $\mathrm{M} 21^{\mathrm{T}}$, we conclude that this isolate should be classified as a novel species within the Q-7-containing group of the genus Pichia. We propose the name Pichia myanmarensis, with $\mathrm{M} 21^{\mathrm{T}}\left(=\mathrm{NBRC} 11090^{\mathrm{T}}=\mathrm{JCM} 12922^{\mathrm{T}}\right.$ $=$ CBS $9786^{\mathrm{T}}$ ) as the type strain.

\section{Latin diagnosis of Pichia myanmarensis Nagatsuka, Kawasaki et Seki sp. nov.}

In medio liquido $\mathrm{YM}$ post dies 3 ad $24^{\circ} \mathrm{C}$, cellulae sphaeroidae vel ovoideae $(1 \cdot 9-4 \cdot 1 \times 2 \cdot 1-6 \cdot 1 \mu \mathrm{m})$, singulae aut binae, per gemmationem multipolarem reproducentes. In medio liquido fermentatione sedimentum et pellicula tenuis formantur. In agaro YM post dies 3 ad $24^{\circ} \mathrm{C}$, cultura lineariz albida vel cremea et nitida cum margine glabra et convexa sublimitas. In

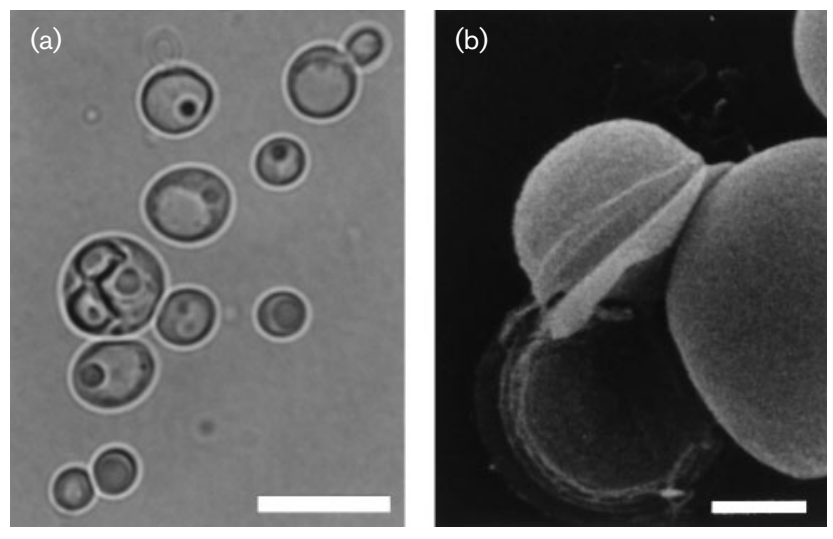

Fig. 2. (a) Micrograph of $P$. myanmarensis $M 21^{\top}$, showing vegetative cells and sporulated cells grown on ME agar for 3 days at $24^{\circ} \mathrm{C}$. Bar, $5 \mu \mathrm{m}$. (b) Scanning electron micrograph of an ascospore of $P$. myanmarensis $\mathrm{M} 21^{\top}$. Bar, $1 \mu \mathrm{m}$. agaro farinae Zea mays post dies 7 ad $24^{\circ} \mathrm{C}$, pseudomycelium nullum. Asci formati sine conjugatione. In agaro $\mathrm{ME}$, farinae Zea mays, aceti et $\mathrm{YM}$ post dies 3 ad $24{ }^{\circ} \mathrm{C}$, ascosporae petasae $(1 \cdot 1-1 \cdot 5 \times 1 \cdot 6-2 \cdot 3 \mu \mathrm{m}), 1-4$ in quoque asco. Glucosum, galactosum (occulutus), sucrosum, maltosum (occulutus) et raffinosum (infirme) fermentatur, sed non lactosum et trehalosum. Glucosum, galactosum, sucrosum, maltosum, cellobiosum (tarde), trehalosum, raffinosum (tarde), melezitosum, amylum solubile, D-xylosum (tarde), L-arabinosum (infirme), D-arabinosum (tarde), D-ribosum, ethanolum, glycerolum, erythritolum, ribitolum, D-mannitolum, Dglucitolum, methyl $\alpha$-D-glucosidum, salicinum, acidum Dgluconicum, acidum DL-lacticum, acidum succinicum, et acidum citricum assimilantur, sed non L-sorbosum, lactosum, melibiosum, inulinum, L-rhamnosum, D-glucosaminum, $N$-acetyl-D-glucosaminum, methanolum, galactitolum nec inositolum. Kalium nitricum, kalium nitracum, ethylaminum, L-lysinum et cadaverinum assimilantur. Crescens in medio sine vitamino. Augmentum in 37 et $40{ }^{\circ} \mathrm{C}$ (infirme). Non crescens in 0.01 et $0.1 \%$ cycloheximido. Crescens in $10 \%$ natrio chlorido/5\% glucoso. Non crescens in $50 \%$ glucoso et $0.5 \mathrm{M}$ litio chlorido/liquido YM. Crescens in $0.3 \mathrm{M}$ litio chlorido/liquido YM. Ureum non hydrolysatur. Diazonium caeruleum B non respondens. Amylum non formatur. Systema coenzymatis Q-7 adest. Guaninum et cytosinum acidi deoxyribonucleati 32.2-33.2 mol\% (per HPLC).

Typus stirpis $\mathrm{M} 21^{\mathrm{T}}$ isolatus ex phoinix saccharon, Mandalay Pref., Myanmar. In collectione zymotica Centraalbureau voor Schimmelcultures, Trajectum ad Rhenum, sub no. CBS $9786^{\mathrm{T}}$, typus stirps deposita est.

\section{Description of Pichia myanmarensis Nagatsuka, Kawasaki \& Seki sp. nov.}

Pichia myanmarensis [my.an.mar.en'sis. N.L. fem. adj. myanmarensis pertaining to Myanmar (Burma), where the yeast was originally isolated].

Growth in YM agar: after 3 days at $24{ }^{\circ} \mathrm{C}$, cells are spherical to ovoid $(1 \cdot 9-4 \cdot 1 \times 2 \cdot 1-6 \cdot 1 \mu \mathrm{m})$, appearing singly or in pairs. Budding is multipolar (Fig. 2a). Sediment and thin pellicles are formed on the surface of the fermentation medium. Growth on YM agar medium: after 3 days incubation at $24^{\circ} \mathrm{C}$, the streak culture is white to cream in colour, smooth and glossy; it has an entire margin and convex elevation. Dalmau plate culture on cornmeal 
agar: after 7 days incubation at $24^{\circ} \mathrm{C}$, pseudohyphae are not formed. Formation of ascospores: vegetative cells are transformed directly into persistent asci, each containing between one and four hat-shaped ascospores $(1 \cdot 1-1 \cdot 5 \times$ $1 \cdot 6-2 \cdot 3 \mu \mathrm{m}$ ) (Fig. 2). Sporulation is observed on ME, cornmeal, acetate and YM agar after incubation for 3 days at $24^{\circ} \mathrm{C}$. The phenotypic characteristics of the species are shown in a supplementary table in IJSEM Online. Glucose, galactose (latent), sucrose, maltose (latent) and raffinose (weak) are fermented, but lactose and trehalose are not. Glucose, galactose, sucrose, maltose, cellobiose (slow), trehalose, raffinose (slow), melezitose, soluble starch, D-xylose (slow), L-arabinose (weak), D-arabinose (slow), D-ribose, ethanol, glycerol, erythritol, ribitol, D-mannitol, D-glucitol, methyl $\alpha$-D-glucoside, salicin, D-gluconate, DLlactate, succinate and citrate are assimilated as sole carbon sources, whereas L-sorbose, lactose, melibiose, inulin, Lrhamnose, D-glucosamine, $N$-acetyl-D-glucosamine, methanol, galactitol and inositol are not assimilated. Nitrate, nitrite, ethylamine, L-lysine and cadaverine are assimilated as sole nitrogen sources. Grows in vitamin-free medium. Grows at $37^{\circ} \mathrm{C}$, and grows weakly at $40^{\circ} \mathrm{C}$. No growth in the presence of 0.01 or $0.1 \%$ cycloheximide. Grows in $10 \% \mathrm{NaCl}$ plus $5 \%$ glucose. Does not grow on $50 \%(\mathrm{w} / \mathrm{w})$ glucose/yeast-extract agar, or in $0.5 \mathrm{M} \mathrm{LiCl} / \mathrm{YM}$ broth. Grows in $0.3 \mathrm{M} \mathrm{LiCl} / \mathrm{YM}$ broth. Urease-negative. The diazonium blue $\mathrm{B}$ reaction is negative. Tests negative for the production of starch-like substances. The major ubiquinone system is Q-7. The $\mathrm{G}+\mathrm{C}$ content of the nuclear DNA is $32 \cdot 2-33 \cdot 2 \mathrm{~mol} \%$, as determined by HPLC.

The type strain $\mathrm{M} 21^{\mathrm{T}}\left(=\mathrm{NBRC} 11090^{\mathrm{T}}=\mathrm{JCM} 12922^{\mathrm{T}}=\right.$ CBS $9786^{\mathrm{T}}$ ) was isolated from palm sugar on the floor of a storage room in a rum distillery in Mandalay, Myanmar, in 2000.

\section{Acknowledgements}

This work was supported by a Grant-in-Aid for Cooperative Research (A) and (B) (no. 11691153 and no. 15380062) from the Japan Society for the Promotion of Science, Ministry of Education, Culture, Sports, Science and Technology of Japan. We are grateful to the culture collection of the Institute for Fermentation, Osaka, Japan, for kindly supplying the yeast strains. We would also like to thank Dr Mikata Kozaburo of the Institute for Fermentation culture collection (present address: NBRC, Resource Collection Division Biological Resource Center, culture collection) for his great suggestions and excellent technical assistance with the scanning electron microscopy. This paper represents part of the dissertation submitted by Y. Nagatsuka to Osaka University in partial fulfilment of the requirements for a $\mathrm{PhD}$ degree.

\section{References}

De Rijk, P., Neefs, J.-M., Van de Peer, Y. \& De Wachter, R. (1992). Compilation of small ribosomal subunit RNA sequences. Nucleic Acids Res 20 (Suppl.), 2075-2089.

Gutell, R. R. (1993). Collection of small subunit (16S- and 16S-like) ribosomal RNA structures. Nucleic Acids Res 21, 3051-3054.

Hamamoto, M. \& Nakase, T. (1995). Ballistosporous yeasts found on the surface of plant materials collected in New Zealand. 1. Six new species in the genus Sporobolomyces. Antonie van Leeuwenhoek 67, 151-171.

James, S. A., Cai, J., Roberts, I. N. \& Collins, M. D. (1997). A phylogenetic analysis of the genus Saccharomyces based on $18 \mathrm{~S}$ rRNA gene sequences: description of Saccharomyces kunashirensis sp. nov. and Saccharomyces martiniae sp. nov. Int J Syst Bacteriol 47, 453-460.

Kuraishi, H., Katayama-Fujimura, Y., Sugiyama, J. \& Yokoyama, T. (1985). Ubiquinone systems in fungi I. Distribution of ubiquinones in the major families of ascomycetes, basidiomycetes, and deuteromycetes, and their taxonomic implications. Trans Mycol Soc Jpn 26, 383-395.

Kurtzman, C. P. \& Robnett, C. J. (1998). Identification and phylogeny of ascomycetous yeasts from analysis of nuclear large subunit (26S) ribosomal DNA partial sequences. Antonie van Leeuwenhoek 73, 331-371.

Marmur, J. (1961). A procedure for the isolation of deoxyribonucleic acid from micro-organisms. J Mol Biol 3, 208-218.

Mikata, K. \& Nakase, T. (1997). Surface structure of ascospores of genus Nadsonia Sydow. Microbiol Cult Coll 13, 97-102.

Nagatsuka, Y., Kawasaki, H., Limtong, S., Mikata, K. \& Seki, T. (2002). Citeromyces siamensis sp. nov., a novel halotolerant yeast isolated in Thailand. Int J Syst Evol Microbiol 52, 2315-2319.

O'Donnell, K. (1993). Fusarium and its near relatives. In The Fungal Holomorph: Mitotic, Meiotic and Pleomorphic Speciation in Fungal Systematics, pp. 225-233. Edited by D. R. Reynolds \& J. W. Taylor. Wallingford, UK: CAB International.

Tamaoka, J. \& Komagata, K. (1984). Determination of DNA base composition by reversed-phase high-performance liquid chromatography. FEMS Microbiol Lett 25, 125-128.

Yamada, Y., Okada, T., Ueshima, O. \& Kondō, K. (1973). Coenzyme $Q$ system in the classification of the ascosporogenous yeast genera Hansenula and Pichia. J Gen Appl Microbiol 19, 189-208.

Yamada, Y., Kawasaki, H., Nagatsuka, Y., Mikata, K. \& Seki, T. (1999). The phylogeny of the cactophilic yeasts based on the $18 \mathrm{~S}$ ribosomal RNA gene sequences: the proposals of Phaffomyces antillensis and Starmera caribaea, new combinations. Biosci Biotechnol Biochem 63, 827-832.

Yarrow, D. (1998). Methods for the isolation, maintenance and identification of yeasts. In The Yeasts, a Taxonomic Study, 4th edn, pp. 77-100. Edited by C. P. Kurtzman \& J. W. Fell. Amsterdam: Elsevier. 